\title{
MICRO-SIZED DOLOMITE INCLUSIONS IN FERROAN CALCITE CEMENTS DEVELOPED DURING BURIAL DIAGENESIS OF KIMMERIDGIAN REEFS, NORTHERN IBERIAN BASIN, SPAIN
}

\author{
M. ISABEL BENITO,${ }^{1} \mathrm{KYGER}_{\text {C. }}$ LOHMANN, ${ }^{2}$ AND RAMÓN MAS ${ }^{1}$ \\ ${ }^{1}$ Departamento Estratigrafia-U.E.I. de Correlaciones Estratigráficas, Facultad C.C. Geológicas, Universidad Complutense de Madrid-CSIC, 28040 Madrid, Spain \\ ${ }^{2}$ Department of Geological Sciences, The University of Michigan, Ann Arbor, Michigan 48109-1005, U.S.A. \\ e-mail: mibenito@geo.ucm.es
}

\begin{abstract}
Burial diagenesis of the Upper Jurassic Torrecilla Reef Complex is recorded by a complex paragenetic sequence initiated with emplacement of ferroan calcite cements and followed by the precipitation of ferroan saddle dolomite. Ferroan calcite cements contain micro-sized dolomite inclusions (MDIs). Elemental and isotopic compositions of MDIs are virtually indistinguishable from those of ferroan saddle dolomite cements. In contrast to other scenarios for the formation of microdolomite inclusions that invoke either a magnesian calcite precursor or incomplete dedolomitization, the paragenetic relations of MDIs to their host ferroan calcite and their geochemical composition implies formation by fine-scale burial replacement of ferroan calcite by fluids associated with the emplacement of ferroan saddle dolomite.

Petrographic observations and mass-balance considerations suggest that it is unlikely that $\mathrm{Fe}$ and $\mathrm{Mg}$ incorporated into ferroan dolomite could have been derived from the cannibalization of the reefal host rock. Rather, dolomitizing fluids were likely associated with the hydrothermal, low-grade metamorphic event that affected the Cameros Basin during the middle to Late Cretaceous. Interaction of these fluids with preexisting burial cements produced MDIs in the ferroan calcites.
\end{abstract}

\section{INTRODUCTION}

The occurrence of microdolomite inclusions (MDIs) in calcite crystals has been widely reported in the literature, and two explanations have been invoked for their mode of formation and geologic significance: (1) MDIs have been interpreted as evidence for a high-magnesium calcite precursor that was subsequently converted into low-magnesium calcite and MDIs (e.g., Lohmann and Meyers 1978; Meyers and Lohmann 1978; Leutloff and Meyers 1984; Mazzullo 1994; Tobin and Walker 1998; Dickson 2001) or (2) MDIs are relics of a dolomite precursor that has undergone partial calcitization (e.g., Evamy 1963; Goldberg 1967; Munn and Jackson 1980; Frank 1981; Budai et al. 1984; Jones et al. 1989; Rossi and Cañaveras 1999).

Micro-sized dolomite inclusions in ferroan calcites of the early Kimmeridgian coral reef sequence (Cameros Basin, Northern Spain) (Fig. 1), however, cannot be explained with either of these hypotheses. Their occurrence in ferroan calcite cements, which are interpreted to have precipitated during progressive burial, and the absence of evidence to suggest association with HMC precursors or intervals of dedolomitization, requires an alternative mechanism for their formation. In the Kimmeridgian sequence, it is possible to reconstruct the process by which MDIs formed, inasmuch as they represent an intermediate paragenetic stage in a sequence of burial cements. Although occurring as intracrystalline euhedral to anhedral inclusions within ferroan calcite, their association with saddle dolomite cement, which postdates and overlies ferroan calcite, suggests an origin unrelated to the ferroan calcite cement which hosts them. Rather, MDIs may have formed through a process of partial replacive dolomitization coincident with the emplacement of the saddle dolomites during the late stages of burial and the low-grade metamorphism that affected deposits of the northwestern Cameros Basin (Fig. 1A).
To test this hypothesis, we employ detailed petrographic and fine-scale elemental and isotopic analyses of burial ferroan calcite and later saddle dolomite to define the sequence and timing of their formation, the nature and source of the diagenetic fluids, and the process by which these MDIs were formed.

\section{METHODS}

A total of 150 samples were used for the petrographic and geochemical study of sedimentary and diagenetic features of the Torrecilla Reef Complex, utilizing standard petrographic techniques, cathodoluminescence, SEM petrography, and elemental and isotopic analyses. For each sample, a polished $30 \mu \mathrm{m}$ thin section and matching $150-200 \mu \mathrm{m}$ thick section for microsampling was prepared. Cathodoluminescence (CL) examination was carried out using a Technosyn ${ }^{\circledR}$ cold cathodoluminescent unit operating at $14-17 \mathrm{kV}$ with $350-450 \mu \mathrm{A}$ beam current. CL microphotographs were performed using 800-1600 ASA, $35 \mathrm{~mm}$ slide film. Following examination with CL, all thin sections were stained with Alizarin Red S and potassium ferricyanide (Dickson 1966). For SEM studies, thin sections were etched with $0.2 \% \mathrm{HCl}$ solution for 12 minutes.

Depositional micritic matrix and seven different diagenetic phases were then microsampled from thick sections using the microscope-mounted drilling system and 3 to 30 spot analyses were performed per phase. Sample areas ranged from 300 to $500 \mu \mathrm{m}$ in diameter, resulting in the recovery of $100-150 \mu \mathrm{g}$ powdered samples. Analyses for $\delta^{13} \mathrm{C}$ and $\delta^{18} \mathrm{O}$ values were performed in the Stable Isotope Laboratory at the University of Michigan. All sample powders were roasted in vacuo for one hour at $200^{\circ} \mathrm{C}$, to remove volatile organic contaminants, then reacted at $73^{\circ} \mathrm{C}$ in an automated carbonate reaction system (CarboKiel-I) coupled directly 


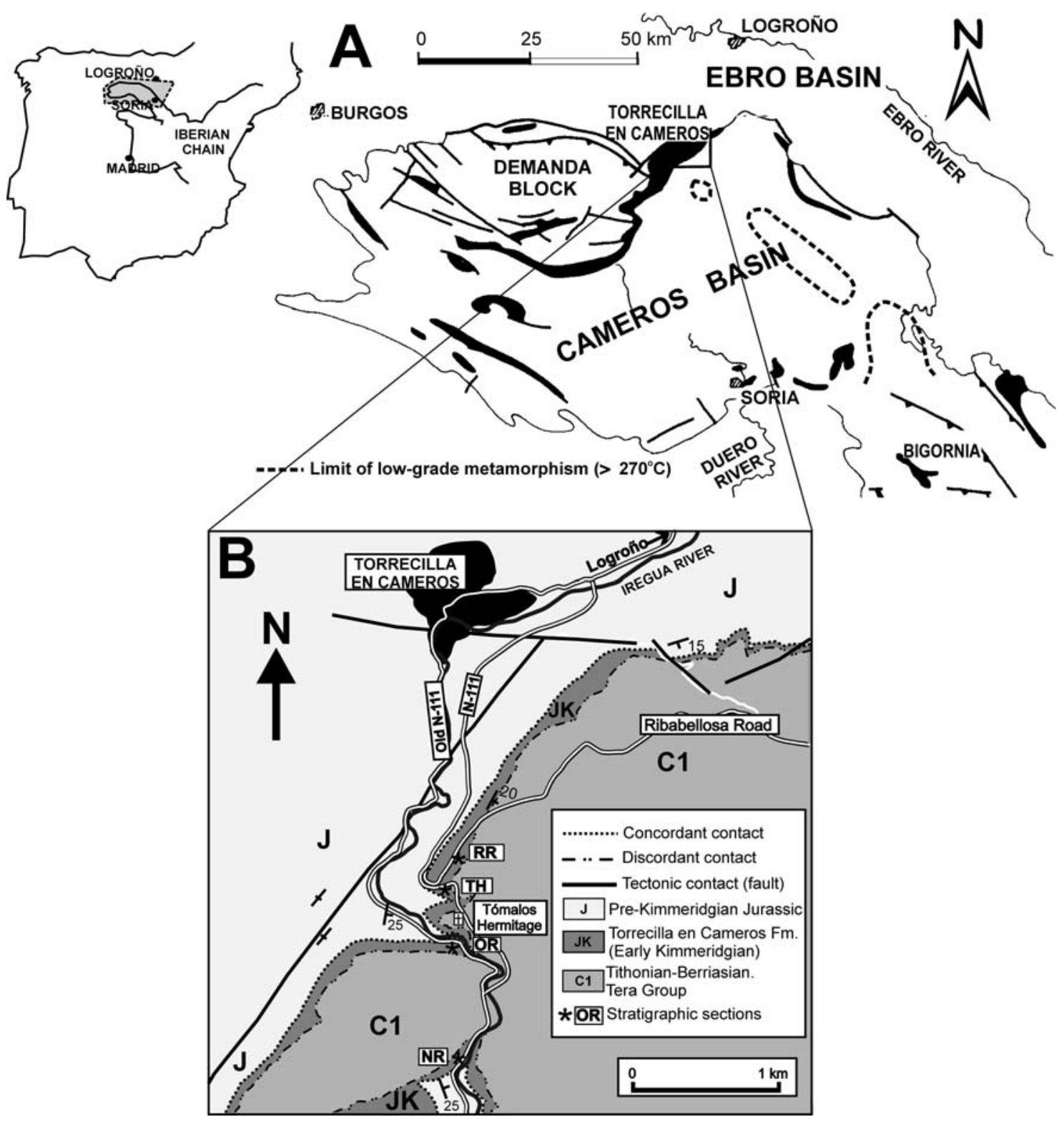

Fig. 1.- Location and geological maps. A) Location of marine Jurassic outcrops (black) around the Cameros Basin. Regional extent of metamorphic alteration (temperatures $>270^{\circ} \mathrm{C}$; within dashed lines) based on Mas et al. (2003). B) Geological map of the locations of the four studied stratigraphic sections.

to the inlet of a Finnigan MAT 251 gas ratio mass spectrometer. Isotopic ratios were corrected for ${ }^{17} \mathrm{O}$ contribution and are reported in per mil notation relative to the VPDB standard. Values were calibrated utilizing NBS 19 as the primary standard, and analytical precision was monitored by daily analysis of NBS powdered carbonate standards. Measured precision was maintained at better than $0.1 \%$ for $\delta^{13} \mathrm{C}$ and $\delta^{18} \mathrm{O}$.

Elemental analyses for $\mathrm{Ca}, \mathrm{Mg}, \mathrm{Sr}, \mathrm{Mn}$, and Fe were performed on an electron microprobe with an accelerating voltage of $15 \mathrm{kV}$ and a spot size of $5 \mu \mathrm{m}$. Measured precision was maintained at better than $\pm 0.14 \%$ for $\mathrm{Mg}, \pm 0.09 \%$ for $\mathrm{Ca}, \pm 0.08 \%$ for $\mathrm{Sr}, \pm 0.08 \%$ for $\mathrm{Fe}$, and $\pm 0.06 \%$ for $\mathrm{Mn}$, and the detection limits were $100 \mathrm{ppm}$ for $\mathrm{Mg}, 250 \mathrm{ppm}$ for $\mathrm{Sr}$, $200 \mathrm{ppm}$ for $\mathrm{Mn}$, and $250 \mathrm{ppm}$ for Fe. Seventeen samples were analyzed, and 12 to 98 spot analyses were performed per phase. To allow direct comparison with isotopic analyses, all elemental analyses were made on the same thick sections.

In order to isolate MDIs from host calcite cement for isotopic analysis, four sample powders of calcite cement containing MDIs were taken from thick sections using the microscope-mounted drilling system. A $1 \mathrm{M}$ solution of acetic acid and sodium acetate with a $\mathrm{pH}$ of 5 was prepared (see Jackson 1969). Each powdered MDI/calcite sample was placed into the solution for 48 hours, and the undissolved powder was then analyzed by XRD to be sure that all calcite was dissolved before isotopic analyses of residual MDIs.

\section{GEOLOGIC SETTING AND STRATIGRAPHIC FRAMEWORK}

The study area is located in the Cameros Basin (Fig. 1), a rapidly subsiding extensional and continental basin developed during the Late Jurassic and Early Cretaceous, which was filled from the Tithonian to middle Albian by up to $5 \mathrm{~km}$ of fluvial and lacustrine deposits with rare marine incursions (Mas et al. 1993; Guimerá et al. 1995; Arribas et al. 2003). These deposits overlie up to $1.5 \mathrm{~km}$ of Triassic and Jurassic rocks (Mas et al. 1993; Guimerá et al. 1995). The basin-fill succession embodies a large cycle or megasequence overlain by an intra-Albian unconformity 


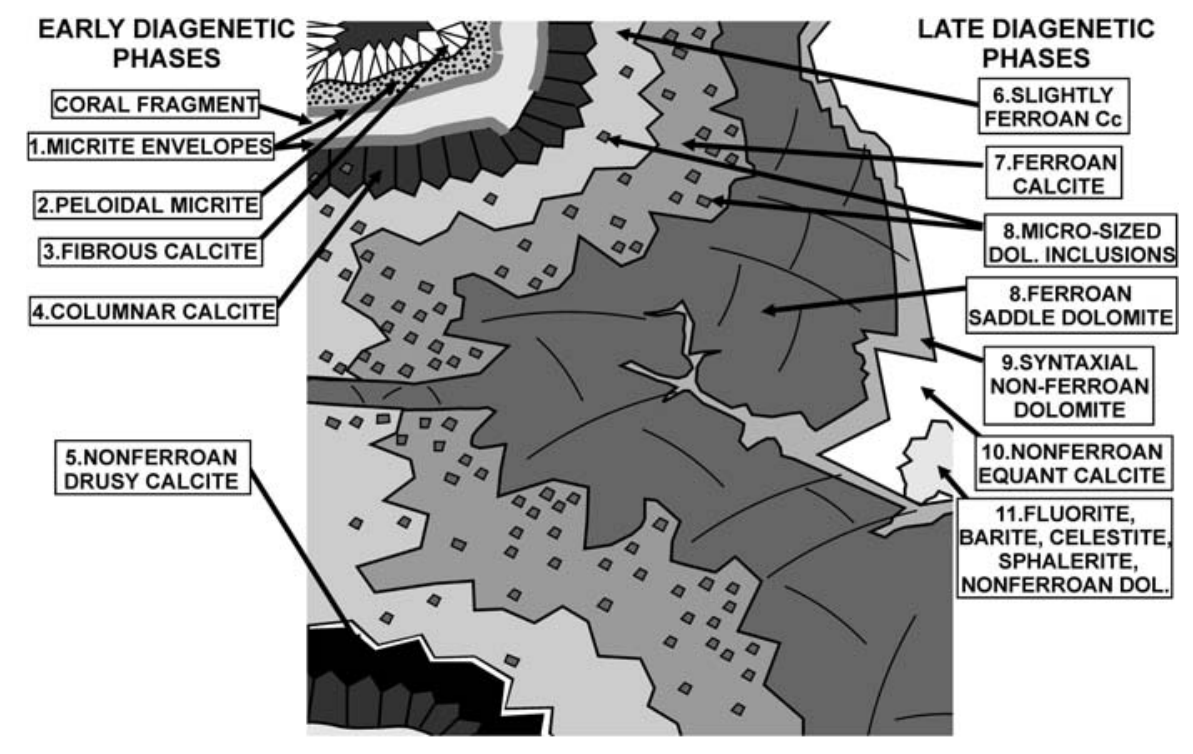

FIG. 2.- Schematic representation of the paragenetic sequence of early (from Benito et al. 2005) and late (this study) diagenetic phases within the Torrecilla Reef Complex. Numbers indicate the order of precipitation of the different diagenetic phases (1, oldest; 11 , youngest). that corresponds to the base of the Upper Cretaceous post-rift megacycle (Mas et al. 1993, Mas et al. 2003; Salas et al. 2001). The basal portion of the Upper Cretaceous megacycle consists of upper Albian sandstones overlain by large Upper Cretaceous carbonate-platform deposits (Alonso et al. 1993; García et al. 2004). The Cameros Basin was subsequently tectonically inverted during Paleogene to middle Miocene alpine contraction (Guimerá et al. 1995; Mas et al. 2003).

One of the main features of this basin is that a large proportion of the Upper Jurassic-Lower Cretaceous deposits of the northwestern area were affected by low- to very low-grade metamorphism (Guiraud and Seguret 1985; Casquet et al. 1992; Mas et al. 1993; Mas et al. 2003) (Fig. 1A). This metamorphism is manifest microscopically by the appearance of chloritoid (an index mineral of low-grade metamorphism) and slaty cleavage oblique to bedding in fine-grained incompetent layers. Pyrite ore deposits in the eastern part of the Cameros Basin are also associated with this metamorphism (Alonso-Azcárate et al. 1999b; Alonso-Azcárate et al. 2001b).

On the basis of a detailed study of the mineralogical, petrological, geochemical, and structural attributes of the basin, this metamorphic episode has been characterized as hydrothermal and allochemical (Casquet et al. 1992; Barrenechea et al. 1995, 2000; Barrenechea et al. 2001; Alonso-Azcárate et al. 1995, 2005; Alonso-Azcárate et al.1999a, Alonso-Azcárate 1999b, Alonso-Azcárate 2001a, Alonso-Azcárate 2001b; Mantilla-Figueroa et al. 1998; Mas et al. 2003). Microthermometry of fluid inclusions, radiometric data, mineral assemblages (chloritoid- chlorite at peak metamorphism), crystallochemical properties of phyllosilicates, chlorite microthermometry, isotopic thermometry, and geochemistry of pyrite deposits indicate that: (1) metamorphism displays clear thermal inversions across areas of rapid deposition; (2) metamorphic grade is more influenced by the changes in rock permeability and composition than by burial depth; (3) metamorphism postdated the filling of the basin (post-rift metamorphic ages range from 106 to 86 Ma (late Albian-Coniacian); and, (4) the metamorphism ranged from low-grade (epizone) to very low-grade (anchizone) conditions, with maximum temperatures and pressures of 350 to $370^{\circ} \mathrm{C}$, and $1 \mathrm{kbar}$, respectively.

This study focuses on the early Kimmeridgian succession, the youngest Jurassic marine unit, which underlies synrift Tithonian to Lower Cretaceous deposits, and is represented by coral-reef complexes of the Torrecilla en Cameros Formation. Specifically, we have examined the Torrecilla Reef Complex, exposed just southwest of Logroño in Northern Spain (Fig. 1B). The reefal succession exposed in this area consists of offlapping reefs, up to $35 \mathrm{~m}$ thick, that developed during relative sea-level fall (Alonso et al. 1986-1987). The Torrecilla Reef Complex was buried by up to $4 \mathrm{~km}$ of Tithonian to Aptian fluvial and lacustrine deposits, and upper Albian to Upper Cretaceous coastal and marine sandstones, limestones, and dolostones (Alonso et al. 1993; Mas et al. 1993; GómezFernández and Meléndez 1994; García et al. 2004). The contact between the reefal and continental units is a major paleosol-associated erosional unconformity surface.

Fig. 3. Cathodoluminescence (CL) photographs showing the early and burial diagenetic phases. A) Coral moldic pore cemented by early diagenetic nonluminescent columnar calcite (CC), followed by brightly luminescent slightly ferroan calcite (fC), a dully luminescent ferroan calcite with brighter luminescent areas which correspond to regions with abundant inclusions (FC) and nonluminescent ferroan saddle dolomite (FD). B) Primary porosity was first cemented by an early diagenetic generation of zoned nonluminescent and bright luminescent nonferroan drusic calcite cement (NFC). NFC was corroded (blue arrow), and then overlain by a bright to dull slightly ferroan calcite ( $\mathrm{fC}$ ) and dark luminescent ferroan calcite $(\mathrm{FC})$, which occludes the pore. C) Burial diagenesis phases in a coral moldic pore. The corroded surface (white arrows) of a nonluminescent ferroan saddle dolomite (FD) is overlain by a thin generation of zoned red luminescent and dark luminescent nonferroan syntaxial dolomite (SD) followed by a nonferroan, brightly luminescent equant calcite (EC). D) Ferroan calcite cement (FC) in a coral moldic pore. Ferroan calcite is affected by a fracture that is filled by ferroan saddle dolomite (FD). Cloudy areas in ferroan calcite (FC) and early calcite cements (ECC) contain abundant micro-sized dolomite inclusions (MDIs). Note that some of the cloudy areas are preferentially concentrated and aligned parallel to the fracture (red arrows), and cut across the brownish growth zones of the calcite crystals (black arrows). E-F) Stained burial diagenetic phases. E) Ferroan calcite cement (FC) is corroded (red arrows), and then overlain by ferroan saddle dolomite (FD). Note the MDIs inside ferroan calcite cements (black arrows). F) MDIs (black arrows) are preferentially concentrated in the areas next to the corrosional boundary between ferroan calcite and ferroan dolomite cements (red arrow). G) Ferroan calcite cement (FC) containing MDIs (red arrows) is followed by ferroan saddle dolomite (FD) after a corrosion surface (yellow arrows). H) Same photograph as part G under polarized light. Note that most of MDIs (red arrows) are in perfect crystallographic continuity with host ferroan calcite. The largest dolomite inclusion (white arrow), however, is in crystallographic continuity with the surrounding ferroan saddle dolomite. 

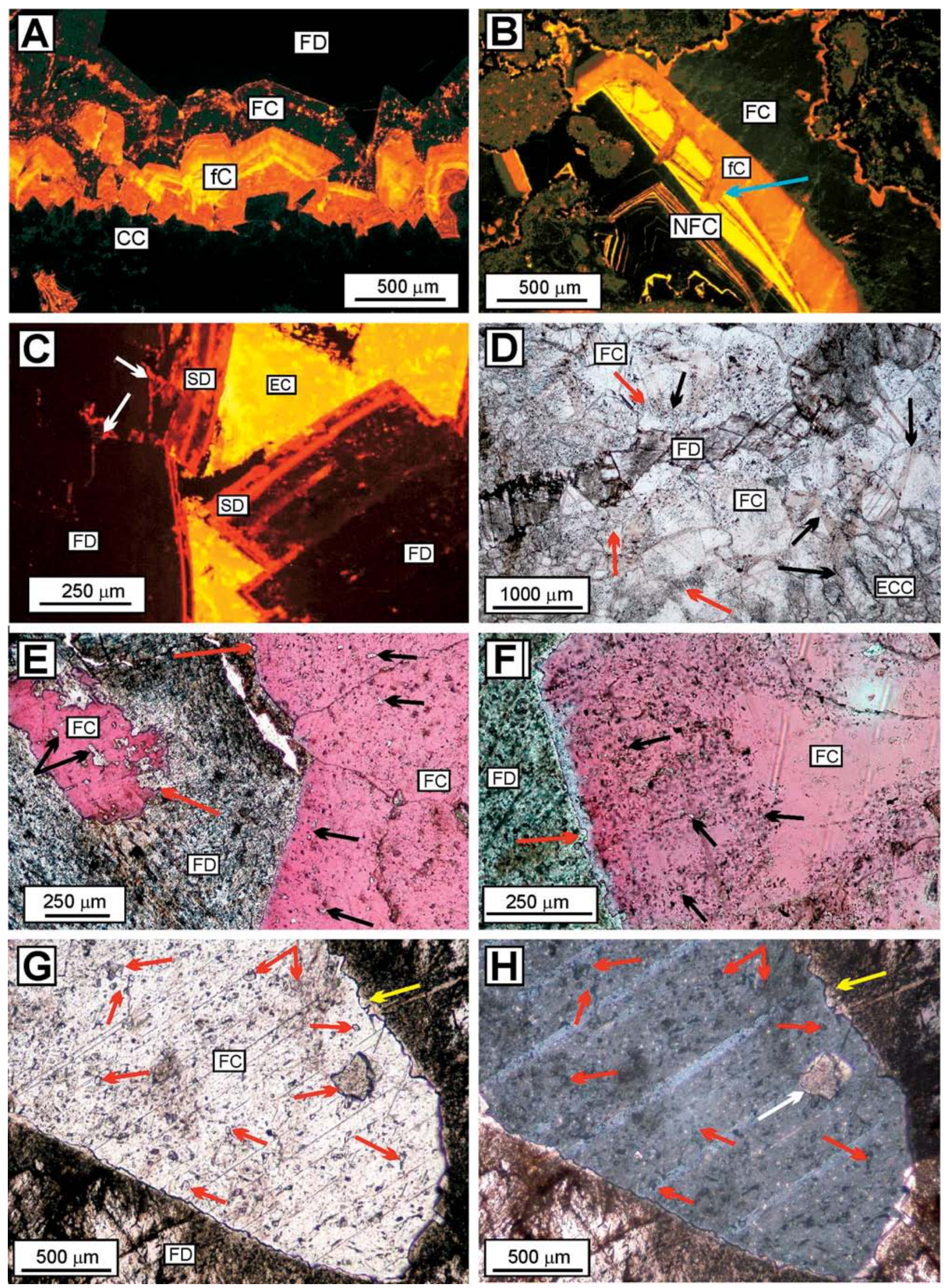
Fibrous calcite and peloidal micrite (Fig. 2) were precipitated syndepositionally in the reefs and were followed by early diagenetic phases during exposure to meteoric waters as detailed by Benito et al. (2005). Early diagenetic processes that affected the reefal complexes were controlled by rising sea level and local tectonism that gave rise to alternations of submergence and reefal exposure; while exposed, reef corals were neomorphosed and dissolved. When submerged, this secondary porosity was then filled by nonferroan columnar calcite cement precipitated from marine-derived waters (Figs. 2, 3A). During the latest stages of reef development, the rate of sea-level rise could no longer keep pace with tectonic uplift, leading to exposure, the development of an extensive paleosol, and the precipitation of nonferroan drusy meteoric calcite cement (Figs. 2, 3B). Subaerial exposure of the reef complex continued until the onset of subsidence and continental sedimentation in the Tithonian.

\section{PETROGRAPHIC OBSERVATIONS AND GEOCHEMISTRY OF LATE DIAGENETIC PHASES}

Early diagenetic cements are postdated by a sequence of late carbonate cements that largely filled remaining primary and secondary porosity (Figs. 2, 3). A common feature of these phases is that $\delta^{13} \mathrm{C}$ values are significantly more negative in samples collected in the upper part of the Torrecilla Reef Complex, compared to those obtained from the lower and middle part (Fig. 4). This pattern of variation of $\delta^{13} \mathrm{C}$ values is similar to that seen in the composition of pre-burial host-rock carbonates, including reefal carbonates and early marine-derived and meteoric cements, which also record progressive upsection depletion in $\delta^{13} \mathrm{C}$ values that has been related to early exposure and alteration of the reef complex (Benito et al. 2005). Specifically, columnar marine-derived cement (Figs. 2, 3A), which is more abundant in the lower and middle part of the sequence (first 25$30 \mathrm{~m}$ ), defines a field of isotopic values that range from -1.2 to $-3.3 \%$ in $\delta^{18} \mathrm{O}$ and from +2 to $-1.2 \%$ in $\delta^{13} \mathrm{C}$ (Fig. 4). The isotopic values of drusy meteoric cements (Figs. 2, 3B), which preferentially precipitated in the upper part of the sequence (last 5-10 m) in association with the subaerial exposure of the reef complex, define a field centered about $-3.5 \% \delta^{18} \mathrm{O}$ and has considerable variation in $\delta^{13} \mathrm{C}$, ranging from -5.3 to $-8.8 \%$ (Fig. 4). Marine micrite has a wide range in both $\delta^{18} \mathrm{O}$ and $\delta^{13} \mathrm{C}$ values, and ranges from -2.1 to $-6.9 \%$ in $\delta^{18} \mathrm{O}$ and from +0.2 to $-6.8 \%$ in $\delta^{13} \mathrm{C}$ (Fig. 4).

The first phase that precipitated after early columnar and drusy calcite cements was a slightly ferroan calcite cement (Fig. 2). This cement exhibits a bright orange luminescence (Fig. 3A, B) and fills fractures that crosscut early diagenetic phases. The boundary between early cements and slightly ferroan calcite is sharp (Fig. 3A) or is defined by a corrosion surface (Fig. 3B). Slightly ferroan calcite is followed by ferroan calcite cement that is darkly dull luminescent (Figs. 2, 3A, B) with a transition that ranges from gradual to sharp. In some cases, slightly ferroan cement is absent, and ferroan calcite is the first burial cement after early diagenetic phases. Both slightly ferroan and ferroan calcites contain little $\mathrm{Sr}$ (up to 0.10 and 0.11 mole $\% \mathrm{SrCO}_{3}$, respectively), or $\mathrm{Mn}$ (up to 0.11 and 0.16 mole $\% \mathrm{MnCO}_{3}$, respectively) (Table 1). $\mathrm{Mg}$ and Fe contents progressively increase from the slightly ferroan to ferroan calcite cements (Table 1). $\mathrm{MgCO}_{3}$ contents of slightly ferroan calcites range from 0.03 to 1.94 mole $\%$, and $\mathrm{FeCO}_{3}$ ranges 0.03 to 0.63 mole \%. In contrast, ferroan calcite $\mathrm{MgCO}_{3}$ contents range from 0.28 to 2.2 mole $\%$ and $\mathrm{FeCO}_{3}$ ranges from 0.5 to 3.0 mole \%. Isotopic compositions of these cements also show a trend towards progressively more negative $\delta^{18} \mathrm{O}$ values and slightly more negative $\delta^{13} \mathrm{C}$ values (Fig. 4). Slightly ferroan calcite cements range from -4.4 to $-6.0 \%$ in $\delta^{18} \mathrm{O}$ values and from +2.4 to $-4.8 \%$ in $\delta^{13} \mathrm{C}$ values. The $\delta^{18} \mathrm{O}$ values of ferroan calcite are more negative and variable than those of the slightly ferroan calcite: $\delta^{18} \mathrm{O}$ values of the early stages of growth of ferroan calcite, which are next to the slightly ferroan calcite, are more positive $(-5.8$ to $-7.0 \%)$ than the later stages of ferroan calcite cement $\left(-6.9\right.$ to $-8.4 \%$ ). In addition, the $\delta^{13} \mathrm{C}$ values of the early stages of growth of ferroan calcite are slightly more positive $(+1.9$ to $-2.8 \%)$ than the later stage $(+1.2$ to $-4.4 \%$ ) (Fig. 4).

Ferroan calcite cement is followed by unzoned, nonluminescent ferroan saddle dolomite (Figs. 2, 3A, C); an irregular corrosional contact separates these two phases (Fig. 3E-H). Ferroan saddle dolomite, with curved crystal and cleavage faces and sweeping extinction in crosspolarized light, occurs as cement infilling the remanent fabric-specific pores and fractures (Figs. 2, 3A, D), and as replacive patches, up to $10 \mathrm{~cm}$ wide, in reefal host rock. The abundance of this dolomite phase is minor, at most constituting $2 \%$ of the total reefal rock volume. Although part of the ferroan dolomites contain sufficient $\mathrm{Fe}$ to be considered ankerites, here we refer to all as ferroan saddle dolomites. They have Fe contents ranging from 3.9 to 20.5 mole $\%$ (Table 1). However, Fe content varies by no more than 4 to 5 mole \% within any single crystal and exhibits no discernible temporal or spatial trends in concentration. $\mathrm{Mg}$ ranges from 27.4 to 44.8 mole \%, and $\mathrm{Ca}$ from 47.7 to 55.7 mole \%. Ferroan saddle dolomites contain little $\mathrm{Mn}$ (up to 0.2 mole \%) and $\mathrm{Sr}$ (up to 0.08 mole \%) (Table 1). $\delta^{18} \mathrm{O}$ values are quite constant, ranging from -5.1 to $-6.4 \%$, whereas $\delta^{13} \mathrm{C}$ values are variable, ranging from +2.1 to $-3.7 \%$. (Fig. 4).

When occurring as cement, the ferroan saddle dolomite can be overlain by a syntaxial nonferroan saddle dolomite that is zoned with alternating red, dark brown, or no luminescence (Figs. 2, 3C). This nonferroan saddle dolomite overlies ferroan saddle dolomite along an irregular and corrosional boundary, with the red-luminescent dolomite typically penetrating the underlying nonluminescent ferroan dolomite (Fig. 3C). Nonferroan syntaxial dolomite cement contains little Fe (0.7 to 4.1 mole $\%$ ), and very low $\mathrm{Mn}$ (up to 0.09 mole \%) and $\mathrm{Sr}$ (up to 0.07 mole \%) (Table 1). Mg ranges from 45.3 to 50 mole $\%$, and $\mathrm{Ca}$ from 48.1 to 51.4 mole $\%$. The $\delta^{18} \mathrm{O}$ values range from -4.9 to $-5.6 \%$, and $\delta^{13} \mathrm{C}$ values from -0.6 to $-1.1 \%$ (Table 1 ).

The youngest diagenetic phases in this reefal unit include trace amounts of nonferroan equant calcite cement (Figs. 2, 3C), fluorite, sphalerite, celestine, barite, nonferroan saddle dolomite, and solid hydrocarbons. These latest phases precipitated in pores and fractures that developed in response to the Tertiary Alpine contraction (Benito et al. 2003; Benito and Mas 2005).

An important accessory component in this sequence of late diagenetic phases is dolomite that occurs as micro-sized inclusions within ferroan calcite and, less commonly, in slightly ferroan and earlier calcite cements (Figs. 2, 3D-H, 5). These micro-sized dolomite inclusions (MDIs) occur only in samples where ferroan saddle dolomite is present (Figs. 3D-H, 5) and do not occur in samples where ferroan calcite is the latest cementfilling porosity (Fig. 3B). When present, MDIs are preferentially concentrated in the areas adjacent to the corrosional boundary between ferroan calcite and overlying ferroan saddle dolomite (Figs. 3D-H, 5A, B). MDIs are also distributed along cleavage planes within the ferroan calcite (Fig. 5E, F) and along shear planes that cut across the growth zones of the ferroan calcite crystals (Fig. 3D). The size of MDIs varies, ranging from less than $1 \mu \mathrm{m}$ to $200-300 \mu \mathrm{m}$. When small, they commonly develop euhedral crystal faces (Fig. 5B-D), whereas larger MDIs, which are preferentially limited to the areas closer to the boundary with the ferroan dolomite cement, commonly have anhedral to subhedral shapes, which may reflect the amalgamation of smaller crystals into larger crystal masses (Fig. 5A-C). The extinction pattern of most of MDIs is congruent with that of the host calcites (Fig. 3G, H). Only some of the largest MDIs have different extinction than the host calcite (Fig. 3H). In this case, MDIs show the same extinction angle as the adjacent ferroan saddle dolomite, suggesting that these MDIs are physically connected to the adjacent ferroan saddle dolomite crystals. 


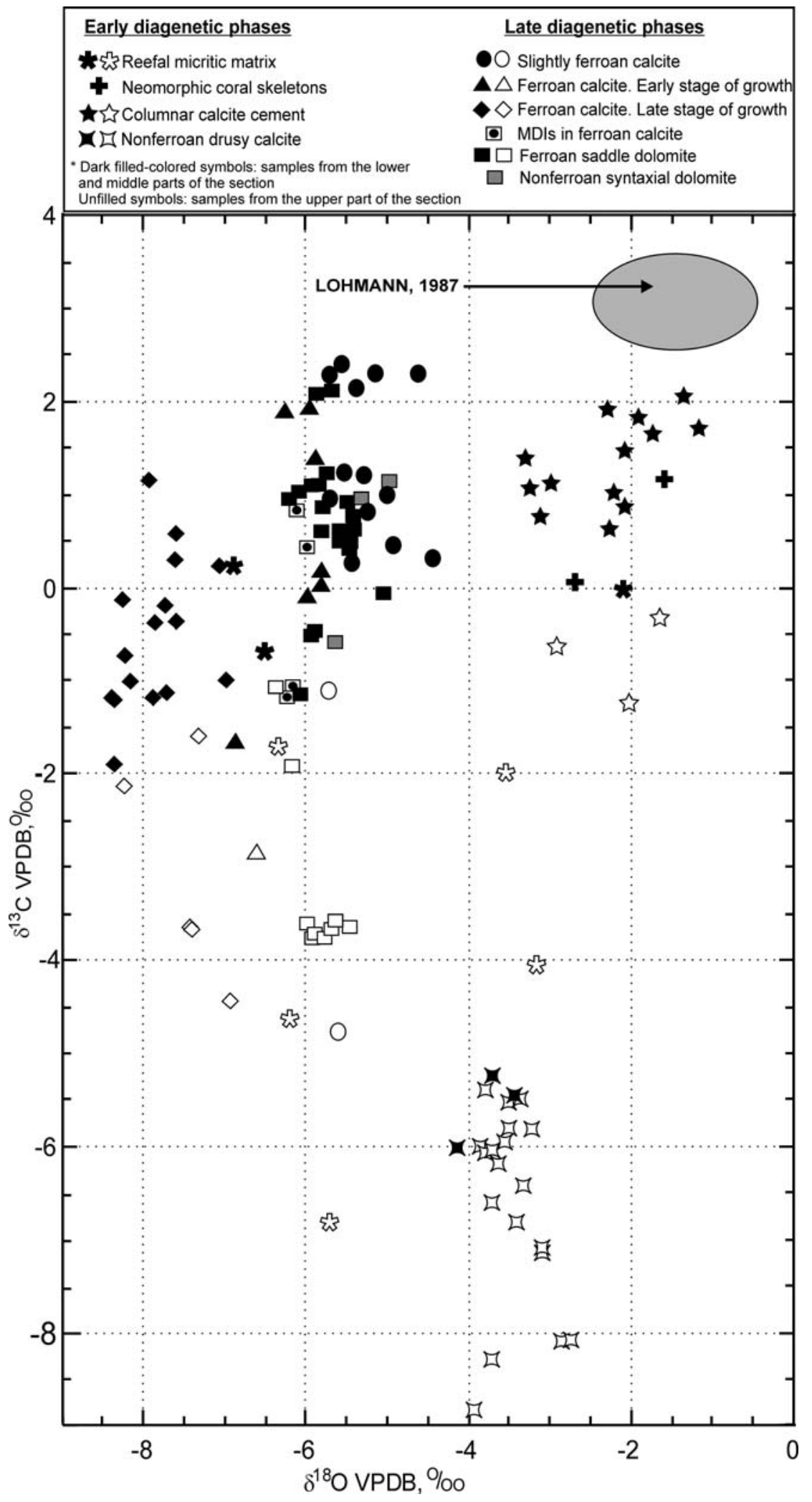

FIG. 4.-Carbon and oxygen isotope compositions of diagenetic phases in the Torrecilla Reef Complex. Isotopic compositions of early diagenetic cements are from Benito et al. (2005). The gray ellipse represents the estimated isotopic composition (mean $\pm 1 \%$ error) of Kimmeridgian abiotic marine calcite (Lohmann 1987)

MDIs have elemental and isotopic compositions very similar to those of ferroan saddle dolomite cement (Fig. 4; Table 1). Fe contents are moderate to high, ranging from 3.1 to 18.2 mole $\%$; $\mathrm{Mg}$ ranges from 30.7 to 46 mole \%, and Ca from 48.1 to 57 mole \%. Mn contents are low, ranging from 0.03 to 0.2 mole $\%$, and $\mathrm{Sr}$ contents are very low, ranging up to 0.11 mole $\%$. Isotopic compositions are relatively invariant in $\delta^{18} \mathrm{O}$, and range from -6 to $-6.2 \%$. The $\delta^{13} \mathrm{C}$ values range from +0.4 to $-1.2 \%$. Importantly, isotopic values of MDIs are quite 
TABLE 1.-Elemental chemistry of the burial diagenetic phases. Detection limits (DL) are indicated by vertical lines. Horizontal black bars are compositional ranges; mean values are shown as white vertical bars, and standard deviations as gray horizontal bars (those below detection limit are omitted). The range of $\mathrm{Mg}$ and Fe contents in dolomites is shown by numbers, with mean values ( $\mathrm{m}$ ) and standard deviation ( $\sigma)$ in parenthesis. $\mathrm{N}$ is the number of elemental analyses; $\mathrm{n}$ is the number of isotopic analyses. Note that scales for Sr and Mn content have been expanded. The column in the left margin shows the order of precipitation of each diagenetic phase (1: oldest; 4: youngest).

\begin{tabular}{|c|c|c|c|c|c|c|c|c|c|c|}
\hline $\begin{array}{c}\text { ORDER } \\
\text { OF } \\
\text { PRECIP. }\end{array}$ & $\begin{array}{c}\text { BURIAL DIAGENETIC } \\
\text { CARBONATES } \\
\end{array}$ & LUMINES & \begin{tabular}{|c|}
$\mathrm{SrCO}_{3}$ \\
$(\mathrm{~mol} \mathrm{\% )}$ \\
0. \\
\end{tabular} & $\begin{array}{r}\mathrm{MgCO}_{3}(\mathrm{~mol} \%) \\
1 \quad 2 \\
\end{array}$ & $\begin{array}{l}\mathrm{FeCO}_{3}(\mathrm{~mol} \%) \\
\left.0 \begin{array}{c}1 \\
0\end{array}\right] \\
\end{array}$ & $\begin{array}{r}\mathrm{MnCO}_{3} \\
(\mathrm{~mol} \mathrm{\% )}) \\
0 \quad \quad 0.2 \\
\end{array}$ & N & $\delta^{13} \mathrm{C}, \% 0$ & $\delta^{18} 0, \% 0$ & $n$ \\
\hline 1 & $\begin{array}{c}\text { SLIGHTLY } \\
\text { FERROAN Cc } \\
\end{array}$ & $\begin{array}{c}\text { Bright } \\
\text { orange }\end{array}$ & & & a & 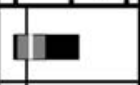 & 98 & +2.4 to -4.8 & -4.4 to -6.0 & 17 \\
\hline 2 & $\begin{array}{l}\text { FERROAN } \\
\text { CALCITE }\end{array}$ & Dull & & Up to 2.2 & Up to 3 & & 75 & +1.9 to -4.4 & -5.8 to -8.4 & 29 \\
\hline 3 & $\begin{array}{c}\text { FERROAN SADDLE } \\
\text { DOLOMITE }\end{array}$ & Nonlum. & & $\begin{array}{c}27-45 \\
(m=37.3, \sigma=3.4)\end{array}$ & $\begin{array}{c}3.9-20 \\
(m=10.4, \sigma=3.4)\end{array}$ & & 85 & +2.1 to -3.7 & -5.1 to -6.4 & 30 \\
\hline 3 & $\begin{array}{l}\text { MDIs IN SLIGHTLY } \\
\text { FERROAN CALCITE }\end{array}$ & & & $\begin{array}{c}34.4-42.5 \\
(m=36, \sigma=3.1)\end{array}$ & $\begin{array}{c}3.1-13.4 \\
(m=7.9, \sigma=3.9)\end{array}$ & & 6 & & & - \\
\hline 3 & $\begin{array}{c}\text { MDIs IN FERROAN } \\
\text { CALCITE }\end{array}$ & & & $\begin{array}{c}30.7-46 \\
(m=37.5, \sigma=4)\end{array}$ & $\begin{array}{c}3.1-18.2 \\
(m=10.7, \sigma=3.8)\end{array}$ & & 50 & + 0.4 to -1.2 & -6.0 to -6.2 & 4 \\
\hline 4 & $\begin{array}{c}\text { NON-FERROAN } \\
\text { SYNTAXIAL DOLOMIT. }\end{array}$ & $\begin{array}{l}\text { Zoned red/ } \\
\text { dull/nonl. }\end{array}$ & 1 & $\begin{array}{c}45.3-50 \\
(m=48, \sigma=1.5)\end{array}$ & $\begin{array}{c}0.7-4.1 \\
(m=2.3, \sigma=0.9)\end{array}$ & & 12 & +0.6 to -1.1 & -4.9 to -5.6 & 3 \\
\hline
\end{tabular}

similar to those of ferroan saddle dolomite occurring in the same samples (Table 2).

\section{DISCUSSION: EVOLUTION OF THE DIAGENETIC SYSTEM DURING BURIAL}

\section{Slightly Ferroan and Ferroan Calcite Cements}

Petrographic, elemental, and isotopic compositions of the slightly ferroan and ferroan calcite cements suggest that they precipitated during progressive burial of the reefal unit. This is supported by their elevated $\mathrm{Mg}$ and $\mathrm{Fe}$ contents and by $\delta^{18} \mathrm{O}$ compositions that gradually decrease from starting $\delta^{18} \mathrm{O}$ values of early marine-derived and meteoric cements (mean values $=-2.3 \%$, and $-3.5 \%$, respectively) to the progressively more negative $\delta^{18} \mathrm{O}$ values of slightly ferroan calcite, early ferroan calcite, and late ferroan calcite (mean values $=-5.3 \%,-6.2 \%$, and $-7.8 \%$, respectively) (Fig. 4). These elemental and isotopic changes are compatible with a progressive decrease in the Eh of burial pore waters and a concomitant increase in temperature, respectively (e.g., Dickson and Coleman 1980; Meyers and Lohmann 1985; Choquette and James 1990).

Carbon isotope compositions of slightly ferroan and ferroan calcites also show a general trend toward slightly more negative values. For example, the heaviest $\delta^{13} \mathrm{C}$ values of slightly ferroan calcite, early ferroan, and late ferroan calcite progressively decrease from $+2.4 \%$, to $+1.9 \%$ and $+1.2 \%$, respectively (Fig. 4). This change is also compatible with cementation during progressive burial (e.g., Dickson and Coleman 1980; Choquette and James 1990). More importantly, the $\delta^{13} \mathrm{C}$ values of ferroan calcite cements are significantly more negative in the upper part of the reefal unit compared to cements occurring in the middle and lower part (Fig. 4). We interpret this stratigraphic trend to be inherited from the $\delta^{13} \mathrm{C}$ values of host reefal carbonate whose composition reflects earlier stages of alteration. In response to late Kimmeridgian subaerial exposure and localized input of highly ${ }^{13} \mathrm{C}$ depleted soil-gas $\mathrm{CO}_{2}$, meteoric alteration gave rise to $\delta^{13} \mathrm{C}$ compositions in the upper part of the reef, which are significantly more negative than host-rock compositions of the middle and lower reefs (Benito et al. 2005) (Fig. 4). Progressive increase in $\delta^{13} \mathrm{C}$ values with stratigraphic distance from the surface of meteoric recharge is a trend predicted for increased rock-water exchange reactions (Allan and Mathews 1982; Lohmann 1987). Inheritance of these host-rock $\delta^{13} \mathrm{C}$ values by later burial ferroan cements requires dissolution of some of the preexisting host rock and equilibration of fluid $\delta^{13} \mathrm{C}$ values to local host rock values (i.e., in a rock-buffered system with respect to carbon), while a pattern of progressive decrease of $\delta^{18} \mathrm{O}$ values within the burial cements requires a water-dominated diagenetic system with respect to oxygen.

\section{Formation of Micro-Sized Dolomite Inclusions}

The occurrence of MDIs as a phase developed within the burial paragenetic sequence provides an opportunity to determine the conditions for their formation. Furthermore, examination of their geochemical and petrographic characteristics allows the elucidation of the microscale process associated with their emplacement. Prior models for the creation of MDIs within preexisting carbonates include the diagenetic stabilization of a HMC precursor in a relatively closed intracrystalline system (e.g., Lohmann and Meyers 1977; Meyers and Lohmann 1978) and the preservation of dolomite relics during dedolomitization (e.g., Goldberg 1967; Frank 1981; Jones et al. 1989). The MDIs in ferroan calcite cements cannot be accounted for by either of these processes.

It is not reasonable to invoke a $\mathrm{HMC}$ precursor for slightly ferroan and ferroan calcite cements within which the MDIs are developed. HMC calcite cements typically precipitate in the marine environment, and it is through their transformation during early diagenesis that they are converted to stable mineralogical phases of LMC and microdolomite. The microdolomites formed by this mechanism are typically 10-30 microns in size and occur within host cements that exhibit fabrics characteristic of neomorphic replacement. In the Cameros Basin, MDIs are highly variable in size $(1-300 \mu \mathrm{m})$ and develop both as irregular anhedral patches and as fine euhedral inclusions (Fig. 5). Moreover, MDIs occur in the ferroan calcite host cements that show no petrographic evidence of recrystallization and are clearly not former marine precipitates.

Six lines of evidence indicate that it is also unreasonable to invoke a process of incomplete calcitization (dedolomitization) of an earlier dolomite cement: (1) During dolomite calcitization, the dolomite 

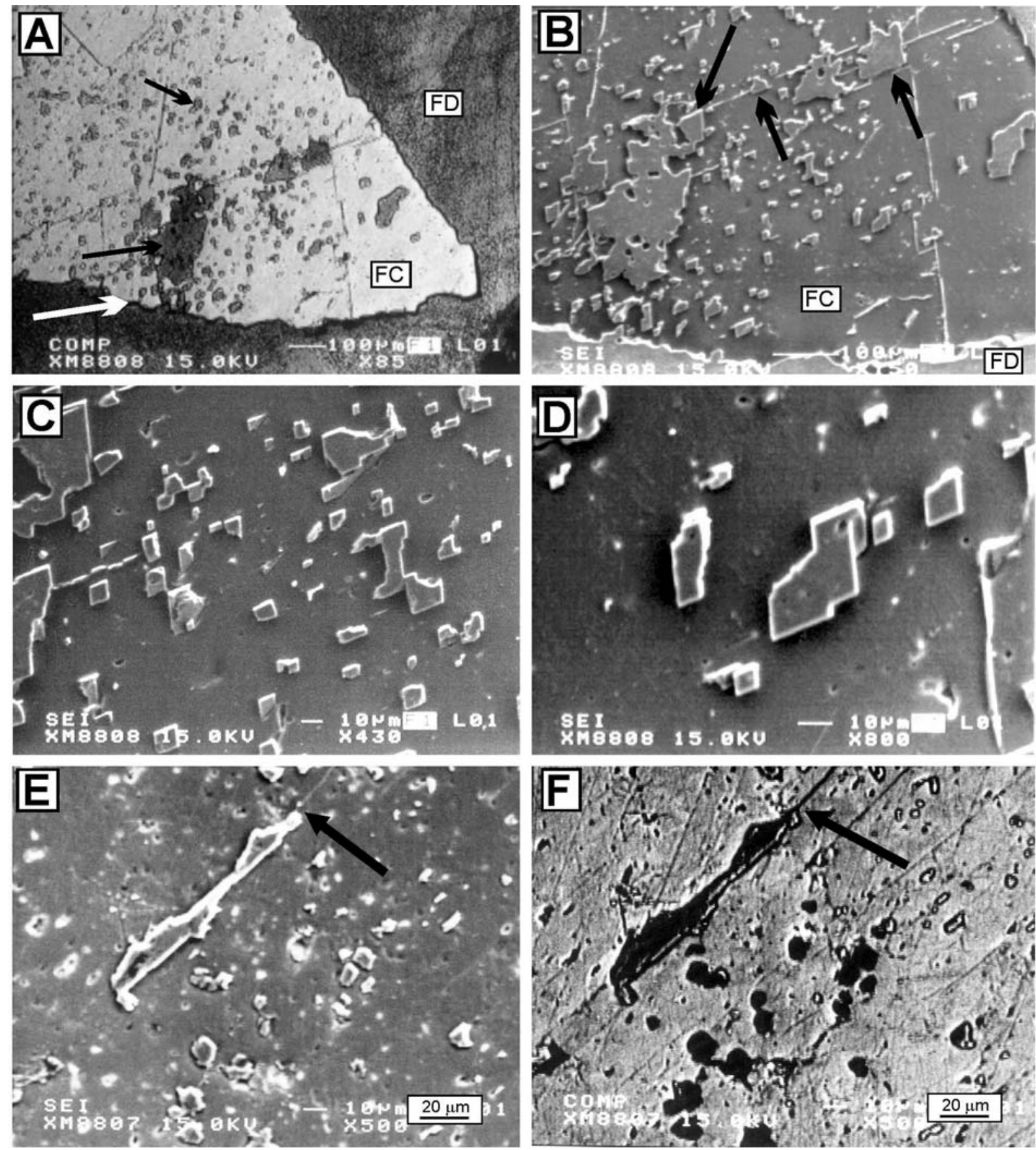

FIG. 5.-SEM images of MDIs. Note that there are no voids between calcite and dolomite. A) Backscattered image showing a corroded (white arrow) crystal of ferroan calcite cement (FC) containing MDIs (black arrows), followed by ferroan saddle dolomite (FD). B) Secondary electron image of lightly etched ferroan calcite and included MDIs. Note that larger MDIs are more anhedral, and the straight margins of some of these MDIs are parallel to lines of cleavage (black arrows). C) Secondary electron image of some euhedral (the smaller) to subeuhedral (the larger) MDIs. D) Secondary electrons image of some small euhedral MDIs. E, F) Secondary electrons and backscatter images of a MDI formed along a cleavage plane (black arrows).

precursor is dissolved and replaced by calcite that fills the available space; thus dolomite relics are irregular and anhedral. In contrast, individual crystals of MDIs of this study commonly show euhedral to subeuhedral faces (Fig. 5). (2) Luminescent zonation and paragenetic relations clearly indicate that slightly ferroan and ferroan calcite precipitated as primary cements filling free space, not as a replacement of a dolomite precursor. Ferroan calcite crystals display euhedral growth zones that nucleated at the margins of primary and secondary pores, which, in turn, were mostly created during the early stages of meteoric diagenesis (Fig. 3A, B) Moreover, the external surfaces of ferroan calcite crystals exhibit evidence of corrosion in contact with ferroan dolomite (Fig. 3D-H), suggesting a process of calcite alteration prior to or during ferroan dolomite precipitation, not the opposite. (3) MDIs do not occur in samples where ferroan saddle dolomite is absent and ferroan calcite is the latest cementfilling porosity (Fig. 3B). This suggests that the MDIs appearance is directly related to occurrence of ferroan dolomite. (4) In most cases, the 
TABLE 2.-Comparison of the isotopic compositions of the ferroan saddle dolomites and MDIs obtained from the same samples.

\begin{tabular}{lcccrcc}
\hline \hline \multicolumn{3}{c}{ Ferroan Saddle Dolomite } & & \multicolumn{2}{c}{ MDIs } \\
\cline { 1 - 2 } \cline { 5 - 6 } Sample & $\delta^{13} \mathrm{C}, \% 0$ & $\delta^{18} \mathrm{O}, \% 0$ & & $\delta^{13} \mathrm{C}, \% 0$ & $\delta^{18} \mathrm{O}, \% 0$ \\
\hline CCGT411 & -1.12 & -6.08 & & -1.06 & -6.17 \\
& & & & -1.16 & -6.24 \\
CCGT414-1 & 0.61 & -5.60 & & 0.84 & -6.11 \\
CCGT414-2 & 0.50 & -5.60 & & & \\
BR103-1 & 1.10 & -5.95 & & 0.43 & -5.99 \\
BR103-2 & 1.11 & -5.88 & & & \\
BR103-3 & 0.62 & -5.83 & & \\
\hline
\end{tabular}

extinction of MDIs is the same as that of the host calcite crystals, suggesting that MDIs grew in optical continuity with the host calcite crystals, and thus, they were formed after precipitation of ferroan calcite. (5) MDIs have been observed along cleavage planes within the ferroan calcite (Fig. 5E, F) and along shear planes that cut across growth zones of the ferroan calcite crystals (Fig. 3D). Therefore, MDIs necessarily precipitated after the host calcite. (6) Significantly, the elemental and isotopic compositions of most MIDs are quite similar to those of the ferroan saddle dolomite (Fig. 4, Table 2). In this sense, it is difficult to argue that an earlier dolomite, with a specific geochemical composition, precipitated after the early diagenetic cements and was subsequently partially to completely replaced by the ferroan calcite. This, in turn, was followed by precipitation of the ferroan saddle dolomite in the remaining porosity, which coincidently has the identical geochemical elemental and isotopic composition of the calcitized dolomite.

Thus, rather than a dolomite precursor undergoing partial replacement by ferroan calcite, it is more plausible that it was the ferroan calcite that was altered and replaced by the MIDs. On this basis, we propose that MDIs formed through the partial dissolution of the preexisting ferroan calcites during the emplacement of the ferroan saddle dolomite. The nature of this replacement varied. Larger and irregular patches of dolomite occur in areas affected by extensive corrosion, such as adjacent to the exterior of the calcite crystals and/or in shear planes (Figs. 3D-H, 5). These larger crystals probably fill irregular microporosity. It is more difficult to explain the development of the intracrystalline MDIs by such a simple dissolution process, because these occur as small subhedral to euhedral crystallites isolated from the margins of the host crystals. The pathways by which dolomitizing fluids penetrated into the interiors of the crystals would presumably be controlled by the network of connected micropores, cleavage, minute fractures, and shear planes in the calcite cements. At sites where dolomite nucleated, continued growth in response to very small differences in solubility of ferroan calcite and ferroan dolomite could explain their euhedral shapes and their isolation as discrete inclusions. This process, as described by Martin et al. (1986) for the progressive microscale replacement of aragonite by calcite, would proceed across a thin fluid film separating the two carbonate phases, and calcite dissolution and dolomite precipitation would occur at such a small scale that substantial voids were not produced.

\section{Saddle Dolomites}

Ferroan saddle dolomite formed after partial corrosion of the ferroan calcite (Figs. 2, 3), in fractures, or as a phase that replaced the host rock. The development of these features suggests that the dolomitizing fluid was undersaturated with respect to calcite, and therefore may have derived some carbonate necessary for dolomite precipitation from the dissolution of calcite within the reefal succession. Moreover, ferroan saddle dolomite shows a wide range of carbon isotope values in a pattern similar to that observed for the ferroan calcites. The most positive values are for dolomite from the lower part of the section, and the most negative values are from the upper part and top of the unit (Fig. 4). Whereas $\delta{ }^{13} \mathrm{C}$ values are variable, ferroan saddle dolomite $\delta^{18} \mathrm{O}$ values are very constant, even in samples where several successive analyses were made within a single crystal. This suggests that both temperature and fluid $\delta^{18} \mathrm{O}$ composition did not change significantly during precipitation.

Nonferroan syntaxial saddle dolomite precipitated after corrosion of the ferroan dolomite (Figs. 2, 3C). However, the isotopic compositions of nonferroan syntaxial dolomites are similar to those of the ferroan dolomites (Fig. 4), suggesting that they precipitated from fluids with similar oxygen isotope compositions and/or at similar temperatures, but with either a higher Eh or no source for Fe.

\section{Source of $\mathrm{Mg}$ and Fe for Dolomitization}

In order to estimate the extent of the water-rock interaction during the emplacement of the saddle dolomite and MDIs, a necessary constraint is the elemental mass balance for $\mathrm{Mg}$ and $\mathrm{Fe}$ needed for precipitation of the volume of dolomite (around $2 \%$ of the total volume of rock). Specifically, we might ask: sufficient $\mathrm{Mg}$ and Fe could be sourced locally through the dissolution of preexisting host rock, or is an extrinsic source necessary?

In order to answer this question, we have taken into consideration the concentration of $\mathrm{Fe}$ and $\mathrm{Mg}$ in the ferroan saddle dolomite (Table 1) and the average chemical composition of the host-rock components (Benito et al. 2005), which include: fossil fragments and micrite (60\%); neomorphosed coral $(15 \%)$; marine-derived cements $(15 \%)$; meteoric cements $(7 \%)$; and ferroan calcite cements $(3 \%)$. On this basis, in order to precipitate $1 \mathrm{cc}$ of ferroan dolomite, it would be necessary to dissolve $32 \mathrm{cc}$ of the host rock to derive the requisite $\mathrm{Fe}$, and $44 \mathrm{cc}$ to obtain sufficient $\mathrm{Mg}$. Thus, the newly formed dolomite would only fill about $2.5 \%$ of the porosity that was created by dissolution of the host rock. This is not consistent with the petrographic and field observations because only minor amounts of dissolution associated with dolomite emplacement are evident petrographically, and ferroan saddle dolomite occurs either as a replacement (on a one-to-one volume basis) or as cement filling primary and secondary porosity that was created during the early stages of meteoric diagenesis. Therefore, it is more likely that the diagenetic system was open during dolomitization, and the $\mathrm{Mg}$ and $\mathrm{Fe}$ needed for precipitation of dolomite were derived from an external source.

We might then ask what fluid $\mathrm{Mg} / \mathrm{Ca}$ ratios were needed for dolomite precipitation. It has been shown that, at temperatures above $60-70^{\circ} \mathrm{C}$, most Ca-rich groundwaters could be dolomitizing fluids (Hardie 1987). Specifically, dolomite is stable in high-salinity brines with a $\mathrm{Mg} / \mathrm{Ca}$ ratio of around 0.7 at $80^{\circ} \mathrm{C}$; this ratio decreases to 0.15 at $200^{\circ} \mathrm{C}$ (Hardie 1987). $\mathrm{These} \mathrm{Mg} / \mathrm{Ca}$ ratios are typical in groundwaters from sedimentary rocks and basinal brines (Hardie 1987; Hanor 1994). Moreover, prior studies have suggested that saddle dolomite generally precipitates from basinal brines with salinities 5 to 7 times greater than seawater, at temperatures ranging between 80 and $200^{\circ} \mathrm{C}$ (Spötl and Pitman 1998). Thus, it is possible that ferroan saddle dolomite precipitated from a fluid with $\mathrm{Mg}$ / $\mathrm{Ca}$ ratio lower than 1.

The source of saline basinal fluids can be discerned from the regional occurrence of late burial dolomite. Ferroan saddle dolomite cements are also observed in coeval Jurassic reefal units in other parts of the basin, as in the southern Bigornia and Soria sectors (Benito et al. 2001; Benito and Mas 2002; Benito et al. 2003) (Fig. 1A). In these places, ferroan dolomite cement occurs at the same position in the paragenetic sequence and is very similar in its petrographical and geochemical character to that described here in the Torrecilla Reef Complex. Based on prior studies (Radke and Mathis 1980; Spötl and Pitman 1998), ferroan saddle dolomite generally precipitates at temperature above $80^{\circ} \mathrm{C}$; this requires a minimum burial depth of $2 \mathrm{~km}$ given a conservative geothermal gradient of $30^{\circ} \mathrm{C}$ per $\mathrm{km}$. 
Although the sequence examined here achieved sufficient depths to reach this temperature, ferroan dolomite is also present in the southern Bigornia area, where maximum burial depth never exceeded $1 \mathrm{~km}$ (Benito et al. 2001). It is therefore apparent that the emplacement of the late ferroan saddle dolomites must record a regional event that is independent of depth of burial. The requirement for elevated temperatures and a source for elemental constituents suggests that high temperature basinal fluids migrated during a single event and led to burial dolomitization in all sectors of the basin.

Precipitation of ferroan saddle dolomite, MDIs, and also nonferroan syntaxial dolomite was likely associated with the hydrothermal metamorphic event that affected the Cameros Basin during the late AlbianConiacian (Benito et al. 2001; Benito and Mas 2002) (Fig. 1A). Upper Jurassic-Lower Cretaceous deposits of the Cameros Basin are composed mainly of Fe-rich sandstones and Fe- and $\mathrm{Mg}$-rich clay minerals. This metamorphic event led to extensive transformation of clays and associated minerals in the northwestern parts of the basin (AlonsoAzcárate et al. 1995, 2005; Alonso-Azcárate et al. 1999b; Barrenechea et al. 1995; Barrenechea et al. 2000; Barrenechea et al. 2001) (Fig. 1A). Additionally, the entire 600-meter-thick Jurassic sequence in the Cameros Basin directly overlies the Triassic Buntsandstein and Keuper facies, which comprise Fe-rich red beds, Mg-rich clays, and evaporites (Mas et al. 1993; Mas et al. 2003; Alonso-Azcárate et al 2005). Thus, it is probable that $\mathrm{Fe}$ and $\mathrm{Mg}$ necessary for saddle dolomite precipitation were sourced by the hydrothermal fluids from either Triassic and/or Upper JurassicLower Cretaceous units.

\section{CONCLUSIONS}

This study describes a new type of micro-sized dolomite inclusions (MDIs) observed within ferroan calcite and suggests a process that can explain their formation during late-stage burial diagenesis. The paragenetic relationship of MDIs to their host ferroan calcites combined with measures of isotopic and elemental chemistry suggests a burial origin for MDIs associated with the emplacement of ferroan saddle dolomite, which postdates the ferroan calcite. The pathways by which dolomitizing fluids penetrated into the interiors of the calcite crystals may have been controlled by the network of interconnected micropores, cleavage, minute fractures, and shear planes in the calcite cements.

Carbon and oxygen isotope data suggest that during precipitation of the burial phases, fluids reacted and exchanged with the host rock such that $\delta{ }^{13} \mathrm{C}$ values are inherited in both the ferroan calcites and the saddle dolomites. On the basis of petrographic features and the elemental composition of the host rock and ferroan dolomite and MDIs, the origin of these fluids can be constrained. It is unlikely that $\mathrm{Fe}$ and $\mathrm{Mg}$ necessary for precipitation of the ferroan dolomite and MDIs were sourced from the dissolution of host-rock carbonate, but rather must have been derived from an extrinsic source. Such fluids likely were associated with the hydrothermal metamorphic event that affected the Cameros Basin during the middle to Late Cretaceous.

\section{ACKNOWLEDGMENTS}

Funds for this study were provided by the Ministerio de Educación y Cultura of Spanish government (projects No. PB97-0298, BTE2001-026, and BTE2002-04453-C02-02) and by a postdoctoral fellowship to the first author by the Comunidad de Madrid and the European Union. The authors would like to thank B.H. Wilkinson, who has significantly improved this manuscript, L. Wingate and J. Alonso-Azcárate for their suggestions and comments, and L. Wingate, G. Herrero, B. Moral, A. Fernández, and I. Sevillano for their technical support. We also thank H. Chafetz, D. Budd, and J.A.D. Dickson for their careful and thoughtful reviews, and K. Milliken and J.B. Southard for their editorial work.

\section{REFERENCES}

Allan, J.R., and Matthews, R.K., 1982, Isotope signatures associated with early meteoric diagenesis: Sedimentology, v. 29, p. 797-817.

Alonso, A., Mas, J.R., And MeléndeZ, N., 1986-1987, Los arrecifes coralinos del Malm en la Sierra de los Cameros (La Rioja, España): Acta Geológica Hispánica, v. 21-22, p. 296-306.

Alonso, A., Floquet, M., Mas, J.R., and Meléndez, A., 1993, Late Cretaceous Platforms: Origin and evolution. Iberian Range, Spain, in Simo, J.A., Scott, R.W., and Masse, J.P., eds., Cretaceous Carbonate Platforms: American Association of Petroleum Geologists, Memoir 56, p. 297-316.

Alonso-Azcárate, J., Barrenechea, J.F., Rodas, M., and Mas, R., 1995, Comparative study of the transition between very low grade and low grade metamorphism in siliciclastic and carbonate sediments, Early Cretaceous, Cameros Basin (North Spain): Clay Minerals, v. 30, p. 409-422.

Alonso-Azcárate, J., Boyce, A.J., Botrell, S.H., MacAulay, C., Rodas, M., Fallick, A.E., AND MAs, R., 1999a, Geochemical development and use of in situ laser sulfur isotope analysis for pyrite-anhydrite geothermometry: an example from the pyrite deposits of Cameros Basin, NE Spain: Geochimica et Cosmochimica Acta, v. 63, p. 509-513.

Alonso-Azcárate, J., Rodas, M., Bottrell, S.H., Raiswell, R., Velasco, F., and MAs, R., 1999b, Pathways and distances of fluid flow during low-grade metamorphism: evidence from pyrite deposits of the Cameros Basin, Spain: Journal of Metamorphic Geology, v. 17, p. 339-348.

Alonso-Azcárate, J., Bottrell, S.H., and Tritlla, J., 2001a, Sulfur redox reactions and formation of native sulfur veins during low grade metamorphism of gypsum evaporites, Cameros Basin (NE Spain): Chemical Geology, v. 174, p. 389-402.

Alonso-Azcárate, J., Rodas, M., Fernández-Díaz, L., Bottrell, S.H., Mas, J.R., and LóPEZ-ANDRÉs, S., 2001b, Causes of variation in crystal morphology in metamorphogenic pyrite deposits of the Cameros Basin (N Spain): Geological Journal, v. 36, p. $159-170$.

Alonso-Azcárate, J., Rodas, M., Barrenechea, J.F., and Mas, R., 2005, Clay minerals as provenance indicators in continental lacustrine sequences: the Leza Formation, Early Cretaceous, Cameros Basin, Northern Spain: Clay Minerals, v. 40, p. 79-92.

Arribas, J., Alonso, A., Mas, R., Tortosa, A., Rodas, M., Barrenechea, J.F., Alonso-AzcÁrate, J., And Artigas, R., 2003, Sandstone petrography of continental depositional sequences of an intraplate rift basin: western Cameros Basin (North Spain): Journal of Sedimentary Research, v. 73, p. 309-327.

Barrenechea, J.F., Rodas, M., AND Mas, J.R., 1995, Clay mineral variation associated to diagenesis and low grade metamorphism of early Cretaceous sediments in the Cameros basin, Spain: Clay Minerals, v. 30, p. 89-103.

Barrenechea, J.F., Rodas, M., Frey, M., Alonso-Azcárate, J., and Mas, J.R., 2000, Chlorite, corrensite and chlorite-mica stacks in Late Jurassic fluvio-lacustrine mudrocks of the Cameros Basin (NE Spain): Clays and Clay minerals, v. 48, p. 256-265.

Barrenechea, J.F., Rodas, M., Frey, M., Alonso-Azcarate, J., and Mas, J.R., 2001, Clay diagenesis and low-grade metamorphism of Tithonian and Berriasian sediments in the Cameros Basin (Spain): Clay Minerals, v. 36, p. 325-333.

Benito, M.I., And Mas, R., 2002, Evolución diagenética de los carbonatos arrecifales de la Formación Torrecilla en Cameros y de los carbonatos continentales suprayacentes (Kimmeridgiense inferior-Titónico) en el Sector de Soria. Cuenca de Cameros. N. España: Journal of Iberian Geology, v. 28, p. 65-92.

Benito, M.I., AND MAs, R., 2005, Evolución sedimentaria y diagenética de los complejos arrecifales kimmeridgienses de la Cuenca de Cameros. La Rioja-Soria: Zubía, v. 14, p. 121-142.

Benito, M.I., Lohmann, K.C., And Mas, J.R., 2001, Discrimination of multiple episodes of meteoric diagenesis in a Kimmeridgian reefal complex, North Iberian Basin, Spain: Journal of Sedimentary Research, v. 71, p. 381-393.

Benito, M.I., Mas, R., and Lohmann, K.C., 2003, Eustatic and tectonic controls on coral reef morphology and porosity: The Torrecilla en Cameros Fm. Early Kimmeridgian, Northern Spain: Crossroad of geology, energy and cultures: American Association of Petroleum Geologists, International Conference and Exhibition, Extended Abstracts, p. 1-6.

Benito, M.I., Lohmann, K.C., And Mas, J.R., 2005, Late Jurassic paleogeography and paleoclimate in the Northern Iberian Basin of Spain: constraints from diagenetic records in reefal and continental carbonates: Journal of Sedimentary Research, v. 75, p. $82-96$.

Budai, J.M., Lohmann, K.C., And Owen, R., 1984, Burial dedolomitization in the Mississippian Madison Limestone, Wyoming and Utah Thrust Belt: Journal of Sedimentary Petrology, v. 54, p. 276-288.

Casquet, C., Galindo, C., González Casado, J.M., Alonso, A., Mas, R., Rodas, M., Garcia, E., and Barrenechea, J.F., 1992, El metamorfismo de la Cuenca de los Cameros. Geocronología e implicaciones tectónicas: Geogaceta, v. 11, p. 22-25.

Choquette, P.W., And James, N.P., 1990, Limestones-the burial diagenetic environment, in Mcllreath, I.A., and Morrow, D.W., eds., Diagenesis: Geoscience Canada, Reprint Series, v. 4, p. 75-111.

Dickson, J.A.D., 1966, Carbonate identification and genesis as revealed by staining: Journal of Sedimentary Petrology, v. 36, p. 491-505.

Dickson, J.A.D., 2001, Transformation of echinoid Mg calcite skeletons by heating: Geochimica et Cosmochimica Acta, v. 65, p. 443-454. 
Dickson, J.A.D., And Coleman, M.L., 1980, Changes in carbon and oxygen isotope composition during limestone diagenesis: Sedimentology, v. 27, p. 107-118.

Evamy, B.D., 1963, The application of a chemical staining technique to a study of dedolomitisation: Sedimentology, v. 1, p. 164-170.

Frank, J.R., 1981, Dedolomitization in the Taum Sauk Limestone (Upper Cambrian), southeast Missouri: Journal of Sedimentary Petrology, v. 51, p. 7-18.

Garcia, A., Mas, R., Segura, M., Carenas, B., Garcia-Hidalgo, J.F., Gil, J., Alonso, A., Aurell, M., Bádenas, B., Benito, M.I., Meléndez, A., and Salas, R., 2004 Segunda fase de postrifting: Cretácico superior, in Vera, J., ed., Geología de España: Madrid, Sociedad Geológica de España, p. 509-522.

Goldberg, M., 1967, Supratidal dolomitization and dedolomitization in Jurassic rocks of Hamakhtesh Hagatan, Israel: Journal of Sedimentary Petrology, v. 37, p. 760-773

Gómez Fernández, J.C., And Meléndez, N., 1994, Estratigrafía de la "Cuenca de Cameros" (Cordillera Ibérica Noroccidental, $\mathrm{N}$ de España) durante el tránsito Jurásico-Cretácico: Revista de la Sociedad Geológica de España, v. 7(1-2), p 121-139.

Guimerá, J., Alonso, A., And Mas, J.R., 1995, Inversion of an extensional-ramp basin by a neoformed thrust: The Cameros basin (N. Spain), in Buchanan, J.C., and Buchanan, P., eds., Basin Inversion: Geological Society of London, Special Publication 88, p. 433-453.

Guiraud, M., AND SEGuret, M., 1985, A releasing solitary overstep model for the Late Jurassic-Early Cretaceous (Wealdian) Soria strike-slip Basin (Northern Spain), in Biddle, K.T., and Christie-Blick, N., eds., Strike Slip Deformation, Basin Formation and Sedimentation: SEPM, Special Publication 37, p. 159-175.

Hanor, J.S., 1994, Physical and chemical controls on the composition of waters in sedimentary basins: Marine and Petroleum Geology, v. 11, p. 31-45.

HARDIE, L.A., 1987, Dolomitization: A critical view of some currents views: Journal of Sedimentary Petrology, v. 57, p. 166-183.

JACKSON, M.L., 1969. Soil Chemical Analysis-Advanced Course, Second edition: Published by the author, Department of Soil Science, University of Wisconsin: Madison, $895 \mathrm{p}$.

Jones, B., Pleydell, S.M, Ng, Kwoi-Choi, and Longstaffe, F.J., 1989, Formation of poikilotopic calcite-dolomite fabrics in the Oligocene-Miocene Bluff formation of Grand Cayman, British West Indies: Bulletin of Canadian Petrololeum Geology, v. 37 p. $255-265$.

Leutloff, A.H., AND Meyers, W.J., 1984, Regional distribution of microdolomite inclusions in Mississippian echinoderms from southwestern New Mexico: Journal of Sedimentary Petrology, v. 54, p. 432-446.

Lohmann, K.C., 1987, Geochemical patterns of meteoric diagenetic systems and their application to studies of palaeokarst: in James, N.P., and Choquette, P.W., eds. Palaeokarst: Berlin, Springer-Verlag, p. 58-80.

Lohmann, K.C., And MeYers, W.J., 1977, Microdolomite inclusions in cloudy prismatic calcites: a proposed criterion from former high-magnesium calcites: Journal of Sedimentary Petrology, v. 47, p. 1078-1088.
Mantilla-Figueroa, L.C., Casquet, C., and Mas, J.R., 1998, Los paleofluidos en el Grupo Oncala, Cuenca de Cameros (La Rioja, España): Datos de inclusiones fluidas, isótopos de oxígeno y SEM: Geogaceta, v. 24, p. 145-148.

Martin, G.D., Wilkinson, B.H., and Lohmann, K.C., 1986, The role of skeletal porosity in aragonite neomorphism-Strombus and Montastrea from the Pleistocene Key Largo limestone, Florida: Journal of Sedimentary Petrology, v. 56, p. 194-203.

Mas, J.R., Alonso, A., And Guimerá, J., 1993, Evolución tectonosedimentaria de una cuenca extensional intraplaca: la cuenca finijurásica-eocretácica de Los Cameros (La Rioja-Soria): Revista de la Sociedad Geológica de España, v. 6, p. 129-144.

Mas, R., Benito, M.I., Arribas, J., Serrano, A., Guimerá, J., Alonso, A., and AlonsoAzcárate, J., 2003, The Cameros Basin (northwest Iberian Chain, North Spain): from Late Jurassic-Early Cretaceous extensions to Tertiary contractional inversionimplications on hydrocarbon exploration: Guidebook, Field Trip 11, American Association of Petroleum Geologists, International Conference: Barcelona, Spain, Centre des Recherches, Elf-Total-Fina, $52 \mathrm{p}$

Mazzullo, S.J., 1994, Lithification and porosity evolution in Permian periplatform limestones, Midland Basin, Texas: Carbonates and Evaporites, v. 9, p. 151-171.

Meyers, W.J., and Lohmann, K.C., 1978, Microdolomite-rich syntaxial cements: proposed meteoric-marine mixing zone phreatic cements from Mississippian limestones, New Mexico: Journal of Sedimentary Petrology, v. 48, p. 475-488.

Meyers, W.J., and Lohmann, K.C., 1985, Isotope geochemistry of regionally extensive calcite cement zones and marine components, in Schneiderman, N., and Harris, P.M., eds., Carbonate Cements: SEPM, Special Publication 36, p. 223-239.

MunN, D., AND JACKSON, D.E., 1980, Dedolomitization of lower Carboniferous dolostone in the Wirksworth area, Derbyshire, England: Geological Magazine, v. 117 , p. 607-612

RadKe, B.M., AND MATHIS, R.L., 1980, On the formation and occurrence of saddle dolomite: Journal of Sedimentary Petrology, v. 50, p. 1149-1168.

Rossi, C., and CaÑaveras, J.C., 1999, Pseudospherulitic fibrous calcite in paleogroundwater, unconformity-related diagenetic carbonates (Paleocene of the Ager Basin and Miocene of the Madrid Basin, Spain): Journal of Sedimentary Research, V. 69 , p. 224-238.

Salas, R., Guimerá, J., Mas, R., Martin-Closas, C., Meléndez, A., and Alonso, A. 2001, Evolution of the Mesozoic Central Iberian Rift System and its Cainozoic inversion (Iberian Chain), in Ziegler, P., Cavazza, W., Roberston, A.H.F., an Crasquin-Soleau, S., eds., Peri-Tethyan Rift/Wrench Basins and Passive Margins: Muséum National d'Histoire Naturelle: Mémoires, v. 186, p. 145-185.

Spötl, C., AND Pitman, J.K., 1998, Saddle (baroque) dolomite in carbonates and sandstones: a reappraisal of a burial-diagenetic concept: International Association of Sedimentologists, Special Publication 26, p. 437-460.

Tobin, K.J., And Walker, K.R., 1998, Diagenetic calcite from the Chazyan group (Vermont): an example of aragonite alteration in a greenhouse ocean: Sedimentary Geology, v. 121, p. 277-288

Received 24 May 2005; accepted 25 August 2005. 